\title{
Pustulosis palmaris et plantaris
}

\author{
Gunalp Uzun, ${ }^{1}$ Ercan Karabacak, ${ }^{2}$ Mesut Mutluoglu, ${ }^{1}$ Ersin Aydin ${ }^{2}$
}

${ }^{1}$ Department of Underwater and Hyperbaric Medicine, Gulhane Military Medical Academy Haydarpasa Teaching Hospital, Istanbul, Turkey ${ }^{2}$ Department of Dermatology, Gulhane Military Medical Academy Haydarpasa Teaching Hospital, Istanbul, Turkey

\section{Correspondence to} Dr Mesut Mutluoglu, drmutluoglu@gmail.com
To cite: Uzun $\mathrm{G}$, Karabacak E, Mutluoglu M, et al. BMJ Case Rep Published online: [please include Day Month Year] doi:10.1136/bcr-2013009400

\section{DESCRIPTION}

A 63-year-old woman presented with multiple painful pustular lesions over both her feet. The patient reported that the lesions used to exacerbate every 1 week in a month for the last 10 years. She claimed to receive several courses of unsuccessful treatment attempts including various medication and off-label drugs. On examination, she had multiple erythematous pustular lesions of $2-7 \mathrm{~mm}$ in diameter over the plantar surfaces of her feet (figure 1). Additionally, similar lesions overlying a desquamated skin were evident on the palmar aspect of her hands (figure 2). Histopathological examination revealed hyperkeratosis with orthoheratosis, acanthosis, spongiosis and papillomatosis. A subgranular pustule, filled with polymorph nuclear neutrophils, was also observed within the epidermis. A diagnosis of pustulosis palmaris et plantaris (PPP) was made. The differential diagnosis of this rare entity should include acute generalised exanthematous pustulosis, acrodermatitis continua, infected eczema, pompholyx and tinea pedis et manuum. Treatment is extremely challenging. Although several topical and systemic agents such as corticosteroids, retinoids, clochicine, methotrexate, ciclosporin and photochemotherapy have been reported to be used with varying efficacies, ${ }^{1}$ there

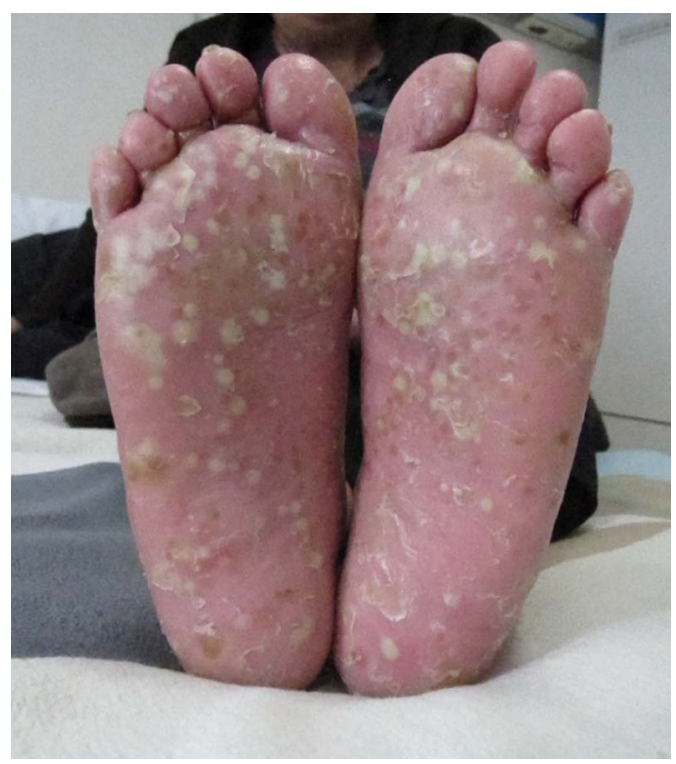

Figure 1 Multiple erythematous pustular lesions of 2$7 \mathrm{~mm}$ in diameter over the plantar surfaces of the feet.

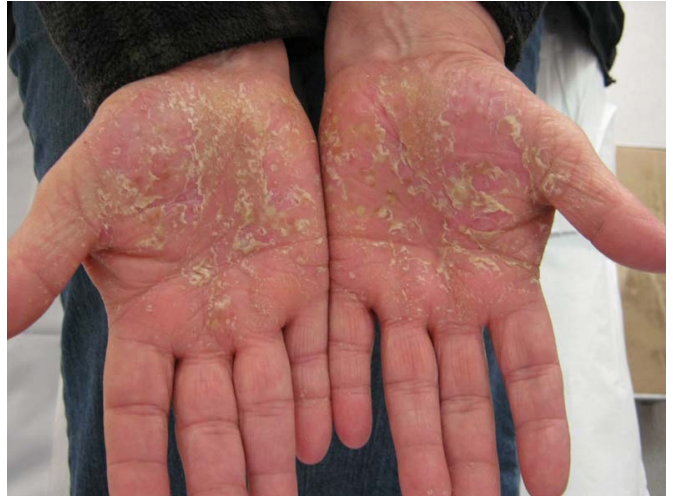

Figure 2 Erythematous pustular lesions overlying the desquamated skin of the palmar aspect of both hands.

is still no established guideline for the management of the disease. Smoking has been postulated to up-regulate the reactivity to PPP, possibly by inducing exposure of more antigens or by changing the surface properties of the acrosyringium (the eccrine sweat duct in the epidermis and stratum corneum), hence cessation of smoking may provide partial relief in some patients. ${ }^{2}$

\section{Learning points}

Patients should be informed about the impact of smoking on pustulosis palmaris et plantaris.

- We need more data and research with regard to the optimal management of pustulosis palmaris et plantaris.

- The differential diagnosis of pustulosis palmaris et plantaris should include tinea pedis et manuum.

\section{Competing interests None.}

Provenance and peer review Not commissioned; externally peer reviewed.

\section{REFERENCES}

1 Adisen $E$, Tekin $\mathrm{O}$, Gulekon $\mathrm{A}$, et al. A retrospective analysis of treatment responses of palmoplantar psoriasis in 114 patients. $J$ Eur Acad Dermatol Venereol 2009;23:814-19.

2 Mrowietz U, Van de Kerkhof PC. Management of palmoplantar pustulosis: do we need to change? $\mathrm{Br} J$ Dermatol 2011;164:942-6. 
Images in...

Copyright 2013 BMJ Publishing Group. All rights reserved. For permission to reuse any of this content visit http://group.bmj.com/group/rights-licensing/permissions.

BMJ Case Report Fellows may re-use this article for personal use and teaching without any further permission.

Become a Fellow of BMJ Case Reports today and you can:

- Submit as many cases as you like

- Enjoy fast sympathetic peer review and rapid publication of accepted articles

- Access all the published articles

- Re-use any of the published material for personal use and teaching without further permission

For information on Institutional Fellowships contact consortiasales@bmjgroup.com

Visit casereports.bmj.com for more articles like this and to become a Fellow 